\title{
The Medical Activities of the London Jews' Society in Nineteenth-Century Palestine
}

\author{
YARON PERRY and EFRAIM LEV*
}

\section{The Medical Situation in Palestine at the Beginning of the Nineteenth Century}

By the end of the eighteenth century, Palestine's once busy medieval trade in medicinal substances and high standard of medical services had reached their nadir. The main reason for this was the prolonged and continuous decline of the Ottoman empire, in conjunction with serious insanitary conditions, poverty and ignorance, as well as a lack of public health facilities. In the absence of sufficient medical care over several generations, the inhabitants of early-nineteenth-century Palestine were forced to rely mainly on folk medicine, and diseases and epidemics were seen as inevitable, the result of fate or decreed by heaven.

A variety of popular folk remedies had been developed, based on old medical treatises and on the medicinal substances used in ancient times, in addition to cures, charms, amulets, and incantations based on superstitious beliefs. Amulets and curative remedies were a common solution for incurable diseases, mainly mental illnesses. The terrible symptoms that accompanied such maladies led those in contact with the patient to believe that magical powers and demons caused them, and that only magical cures could therefore relieve their distress.

The standard of medicine in a country can be measured by the state of the public health system, medical training and medicinal substances. In Palestine, medical science, as distinct from folk medicine, rested on the classical Hippocratic-Galenic medical methods that the Muslims had adopted and improved in the course of the Middle Ages. For most of the Ottoman period, Palestine was considered an area of marginal importance, remote from cultural or government centres, and eminent physicians avoided going there. Nevertheless, it is worth examining the practice of medicine in Jerusalem since it operated on three main levels: public medicine, community medicine, and private medicine. A fourth level, voluntary medicine, gained ground only in the course of the nineteenth century.

In Jerusalem, as in other large cities of the Ottoman empire, only minimal public medical services were offered. Although intended to meet the needs of the population as a whole without discrimination by religion or nationality, these services primarily benefited the Arabs. The public hospital in Jerusalem, a successor to the medical institution of the Ayyubid Caliphate of the twelfth and thirteenth centuries, which functioned throughout the Ottoman period, belonged to a charitable endowment

* Yaron Perry, PhD, and Efraim Lev, PhD, University, Haifa, Mt Carmel 31905, Israel.

Department of Eretz Israel Studies, Haifa 
trust. Its standards, like those of similar institutions, deteriorated as the Ottoman empire itself gradually declined. ${ }^{1}$

It was only in 1886 that the Jerusalem municipality set up a clinic, which opened three times a week, and in 1891 that the new Municipal Hospital was erected in Sheikh Bader (today, $86 \mathrm{Jaffa}$ Street, in the heart of the new city). ${ }^{2}$ Until then, the inhabitants of Jerusalem had to make do with medicinal substances that had been in use throughout the region for centuries. As time passed, disruptions in trade routes brought about a decrease in the variety of available medications. The harsh economic conditions reduced the demand for exotic and expensive products, and the standards of physicians and caregivers fell. ${ }^{3}$ Quinine is the only modern medicinal compound among the scores of substances mentioned in the various historical sources concerning the medical situation in Jerusalem until the beginning of the nineteenth century. This medication was prescribed at the dispensaries of the Franciscan community in Jerusalem during the first half of the eighteenth century. ${ }^{4}$

As treatises on materia medica show, ${ }^{5}$ at that time new pharmaceutical agents from Africa, Asia, and America were important components of medications in Europe. In Palestine and Jerusalem, however, most medicines dispensed by authorized physicians were traditional ones, derived largely from local sources, as their plant, mineral, and animal origins indicated. ${ }^{6}$

Community medicine, which gained adherents in Jerusalem, was essential for the various ethnic groups, providing a necessary alternative to the defective public health system. For religious reasons, Jews and Christians, with the permission of the Ottoman government, preferred to use the medical services provided by their own communities. Muslim almshouses, offering limited medical care, most probably existed too.?

From the sixteenth century to the eighteenth, the centre of community medicine for the Jews of Jerusalem was their own hospital located in the Jewish Quarter,

\footnotetext{
' Z Amar and E Lev, Rof'im u-trufot biYerushalayim be-meot ha-asirit ad ha-shmonehesreh (Physicians, drugs and remedies in Jerusalem from the 10th to the 18th century), Tel Aviv, Eretz, 2000, pp. 74-93.

${ }^{2} \mathrm{~N}$ Levy, Prakim be-toldot ha-refuah be-Eretz Yisrael, 1799-1848 (Chapters in the history of medicine in Palestine, 1799-1948), Haifa, Hakibbutz Hameuchad and the Technion, 1998, pp. 133-5. For further details on the Municipal Hospital, see Z Greenberg, 'Beit ha-holim haironi ha-Turki bi-Yerushalayim' ('The Turkish Municipal Hospital in Jerusalem'), Cathedra, 1995, 78: 49-64.

${ }^{3}$ On the medicinal substances which were used by the inhabitants of Jerusalem until the beginning of the nineteenth century, see $E$ Lev, 'Homreh ha-marpeh bi-Yerushalayim be-meot haasirit ad ha-shmoneh-esreh' ('Medical materials in Jerusalem from the 10th to the 18th century'), in Z Amar, E Lev, J Schwartz (eds), Ha-refuah biYerushalayim le-dorotehah (Medicine in Jerusalem
}

throughout the ages), Tel Aviv, Eretz, 1999, pp. 51-78.

${ }^{4}$ Regarding quinine, see Amar and Lev, op. cit., note 1 above, p. 189.

${ }^{5}$ See, for example, W A Lewis, $A$ complete dictionary of the whole materia medica, 2 vols, London, 1810.

${ }^{6}$ In this connection, see Z Amar and E Lev, 'Homreh ha-refuah ha-masortiyim biYerushalayim al pi Titus Tobler' ('Traditional medicinal substances in Jerusalem according to Titus Tobler'), Harefuah, 2000, 138: 604-7.

${ }^{7}$ Several sources from the eighteenth century refer to "the Hospital of St Helena", which was a hostel for the poor and a "thekia" (a sort of soup-kitchen). See E Horn, Ichnographiae monumentorum terrae sanctae, ed. E Hoade and B Bagatti, Jerusalem, Franciscan Press, 1962, pp. 191-3. F Hasselquist, Voyages and travels in the Levant, London, L Davis and C Reyners, 1766, p. 135. 


\section{The Medical Activities of the London Jews' Society}

where patients stayed until their recovery. ${ }^{8}$ A reliable description of the Jewish hospital, called Bikur Holim, can be found in the writings of the physician Rabbi Rephael Mordecai Malki, who, having received his medical education in Italy, went to Palestine in 1667 and served as the community physician until his death in 1702 . From his account, it appears that the hospital was run by the community treasurer, who in the absence of a physician was the supreme medical authority. ${ }^{9}$

In the Christian community, medical care centred on the Franciscan Order in Jerusalem, the most prominent Christian institution in the Holy Land during the Mameluk period and the first half of the Ottoman era. The Roman Catholic monks who took possession of certain holy sites and supplied pilgrims with services also offered medical care.

A large number of medical practitioners, namely nurses, pharmacists, physicians, and even surgeons, served in the Franciscan medical institutions in Jerusalem until the nineteenth century, most of them having been sent from Italy whither they returned at the end of their period of service. They had access to a richly stocked medical library and a dispensary, both probably founded at the beginning of the seventeenth century. ${ }^{10}$

A reliable description of the contents of the dispensary at the beginning of the eighteenth century is given by a monk, Elzar Horn, who lived in Jerusalem from 1724 to 1744: "The dispensary in Jerusalem is one of the best in the Christian world. The storehouses contain medications of all kinds which were purchased with donated funds, and especially with funds contributed for this specific purpose by the Venetian Republic." "1 The Swedish botanist, Frederick Hasselquist, who visited the institution in 1750, reported: "It was amazing to see the quantities of expensive medications stored there. ... Here they prepare the Jerusalem Balsam so famed in these countries ... it is very effective for all fresh external wounds.... The whole pharmacopoeia [dispensary stock] is valued at several hundred thousand piasters."12 In 1806 the German traveller Ulrich Jasper Seetzen was impressed by the monks' garden where these medicinal substances were produced, and noted that he received "two bottles of real Balsam with written indications of its qualities". ${ }^{13}$

Another aspect of the medical situation in Palestine was the existence of private medicine. A small number of patients in Jerusalem preferred to use the services of private physicians, who attended them in clinics generally set up in rented shops in the city quarters.

The sanitary conditions in Jerusalem at the beginning of the nineteenth century

\footnotetext{
${ }^{8}$ I Freidin, 'Bikur Holim Perushim biYerushalayim, me-hevrah le-bet holim' ('Bikur Holim Perushim in Jerusalem: from society to hospital'), Cathedra, 1983, 23: 117-40.

${ }_{9}^{9}$ M Benayahu, Ma'amarim bi-refuah le-Rabi Refael Malki (Essays on medicine by Rabbi Rephael Mordecai Malki), Jerusalem, Yad Harav Nissim, 1988, pp. 58-68.

${ }^{10}$ H R Schittny, 'Die historische Apotheke der Franziskaner in Jerusalem', Geschichte der Pharmazie, 1993, 45: 41-5; N Schur, 'Franciscan physicians and pharmacists in Jerusalem', in
}

\author{
Amar, Lev and Schwartz, op. cit., note 3 above, \\ pp. 99-105; B Bagatti, 'Father Anthony Manzazi \\ of Cuna (1650-1729), inventor of "The Balm of \\ Jerusalem"', Franciscan Studies, 1946, 6: 250-361; \\ Antonio Cirelli, Gli annali di Terra Santa, \\ Quaracchi, Tipografia del Collegio di S. \\ Bonaventura, 1918, p. 219. \\ ${ }^{11}$ Horn, op. cit., note 7 above, pp. 176-81. \\ ${ }^{12}$ Hasselquist, op. cit., note 7 above, p. 135 . \\ ${ }^{13}$ U J Seetzen, Reisen durch Syrien, Palästina, \\ etc., ed. F Kruse, 3 vols, Berlin, 1854, vol. 2, \\ pp. 205-6.
}




\section{Yaron Perry and Efraim Lev}

were poor. This was mainly because of overcrowded and unventilated housing, piles of rubbish rotting in public places, sewage flowing through the streets, contaminated wells, and a disregard for personal hygiene. Such squalid conditions caused infectious diseases, and periodic epidemics of cholera, bubonic plague, typhoid fever, smallpox, and meningitis claimed many victims. In addition to contagious childhood illnesses, other common complaints were malaria, eye infections, headaches, and dysentery. ${ }^{14}$

Conrad Schick, a German scholar who spent more than fifty years in Jerusalem, gave a good description of the medical situation in Palestine and Jerusalem towards the end of the nineteenth century:

Philanthropic organizations and wealthy individuals who had an interest in the Holy Land ... can function in various spheres in Palestine: there is a lack of hospitals, qualified and experienced physicians and pharmacists in cities and in large population centres such as Hebron, Gaza, Shechem, Jenin, Tiberias, Safed, etc. It is necessary to promote the construction of hospitals and clinics manned by young doctors. It is very important to set up a central institution or hospital and clinic for eye-disease patients in the centre of the country-preferably in Jerusalem. ${ }^{15}$

\section{The London Jews' Society and Its Medical Activities}

Britain showed very little interest in Palestine during the nineteenth century. The British government had no desire to take over Palestine and speed the decline of the "Sick Man on the Bosphorus", as the Ottoman empire was then called. It was anxious, however, to prevent other powers from undertaking any actions that might jeopardize British interests in the East. The loss of the British crown colonies in North America several decades earlier had no doubt cast its shadow over British foreign policy, resulting in priority being given to India and the route that led to it. In addition, some underlying aspects of English Protestantism showed an interest not in the holy sites in Palestine but in the idea of the "Restoration of the Jews". The main tenets of the faith of many Protestants were that the Second Coming of Jesus Christ was imminent and his advent would herald the utopian epoch of the millennium. An important condition for the fulfilment of this apocalyptic vision was the return of the Jews to the land of their fathers and their immediate conversion to Christianity, or, alternatively, their recognition of the Messianic claims of the Christian Saviour.

Some religious people, prompted by a deep sympathy for the Jewish people deriving from the Holy Scriptures, considered their restoration would be a means

\footnotetext{
${ }^{14} \mathrm{~A}$ detailed description of this situation is given by the Swiss physician Titus Tobler. See T Tobler, Beitrage zur Medizinischen Topographie von Jerusalem, Berlin, 1855, pp. 24-63. See also T Chaplin, 'The fever of Jerusalem', Lancet, 1864, ii: 236-8. Dr Masterman concluded the data in: E W G Masterman, Hygiene and diseases in Palestine in modern and Biblical times, London, Palestine Exploration Fund, 1920.

${ }^{15} \mathrm{C}$ Schick, 'Studien über Colonisirung des Heiligen Landes', Österreichische Monatsschrift
}

für den Orient, 1881, 7: 98-100. There is a good description of Western medical activity in E Kass, 'Western medicine in nineteenth-century Jerusalem', J. Hist. Med. Allied Sci., 1989, 44: 447-61. On the political aspects of such activity, see N Schwake, 'Hospitals and European colonial policies in nineteenth and early twentieth centuries', in M Waserman and S S Kottek (eds), Health and disease in the Holy Land, Lewiston, NY, and Lampeter, Edwin Mellen, 1996, pp. $231-62$. 


\section{The Medical Activities of the London Jews' Society}

of atoning for the sins committed by the Church against the Jews. More practical people considered the Jews a useful tool in the process of hastening the return of the Messiah. Both groups gave active support to the return of the Jews to their homeland by attempting to make Palestine a habitable place and by promoting the welfare of the Jews living in the region in order to attract their brethren in the Diaspora. Whatever the motive, the main purpose was still the desire to bring the Jews closer to Jesus, hence also to "redemption". On the basis of this belief, many societies sprang up around the world whose aim was to spread the gospel among the Jews. The most prominent among these was the London Society for Promoting Christianity Amongst the Jews, commonly known as the London Jews' Society. ${ }^{16}$

In 1809, Christian Friedrich Frey, a converted German Jew, founded a modest missionary society in order to spread the gospel among the Jews of East London. Between 1820 and 1840, the London Society despatched a dozen missionaries to Palestine, but various obstacles prevented them from settling permanently in Jerusalem. In the 1820 s, the Ottoman regime, which did not allow any Protestant activity in its realm, was generally held responsible for this. However, even the conquest of Palestine by the Egyptians at the beginning of the 1830s and their subsequent rule for the rest of the decade-during which Cairo pursued a different policy and allowed the missionaries to establish a foothold in Jerusalem-failed to yield the anticipated proselytizing fruits. Only in the 1840s, and then only for a short while, did the Society at last begin to flourish and become the most significant foreign element in Palestine. It was then that British missionaries started to arrive and to thrive.

The missionaries used a variety of methods to draw the Jews of Palestine closer to the Christian faith. Primarily they tried to expose them to the Christian scriptures, establishing a book depot, where texts sacred to Judaism and Christianity were available for sale or distribution. Converted Jews were employed in this repository to read the New Testament to passers-by in their own language. A secular school was also set up for the purpose of influencing the children of the Jewish community, and through them reaching their parents. Members of the Society exploited the fact that Jewish youngsters received only religious instruction in their communities by offering them the alternative of a free and wider education.

But the institutions that proved most successful in terms of religious conversion were the hospitals of the London Society. The Society's leaders were well aware of the poor standard of health among the Palestinian Jews and of the total lack of any Jewish medical facilities. In the early stages of their missionary activities, they had sent physicians to their mission stations, opening dispensaries for the sale and distribution of medicines, and clinics to provide first-aid services. Once the mission stations were well established and the medical needs of the local population were properly assessed, hospitals were built in Jerusalem and Safed. The deep gratitude felt by Jewish patients towards the missionaries who served in the medical institutions

\footnotetext{
${ }^{16}$ On the London Jews' Society, see especially Y Perry, Nesi'im ve-ruah ve-geshem ayin (Clouds and wind without rain), Tel Aviv, Hakibbutz
}

Hameuchad, 2001; Y Perry, British mission to the Jews in 19th century Palestine, London, Frank Cass, 2003. 


\section{Yaron Perry and Efraim Lev}

made them far more receptive and willing to become familiar with the Christian scriptures. Occasionally medical treatment was made conditional upon listening to sermons and studying the New Testament. ${ }^{17}$

\section{The British Hospital in Jerusalem}

The first attempt by the London Society to send a medical missionary, Dr George Dalton, to Palestine in the 1820s failed when he died in Jerusalem in 1826. The modest medical services that were established by the Society in the late 1830 s were abandoned during the second war between the Egyptians and the Ottoman empire in 1840. However, seeing that the work of their missionary doctors had left an impression on the Jews of Jerusalem, the Society's leaders realized how important the enterprise of the 1830 s had been in promoting the Society's goals. Accordingly, they were encouraged to implement their decision of March 1841 to renew their activities after the interruption caused by the war. They resolved to execute the plans for founding a hospital for the Jews; and they determined that next to it "a School be established in Jerusalem under the immediate direction and management of the Head of the Medical department, and in which Surgery and Pharmacology is to be taught". It was also agreed that Dr Edward Macgowan's offer to travel to Palestine and serve as a doctor at the Jerusalem mission should be accepted and that "his professional character stands too high to make it necessary for him to transmit his Testimonials." 18

Macgowan arrived in Jerusalem in January 1842, and at the end of his first month of work he sent a detailed report to the London Society describing the poor state of health of the Jerusalem Jews, his activities among them, and his recommendations for the construction of a hospital and a dispensary. He urged the London Committee to reach some practical decision on this matter, and hinted that it would be possible to economize on the expenses of the medical department by growing medicinal herbs. Macgowan even asked the Society to let him lease some land for this purpose and employ a local worker. While still awaiting permission from London, he began renovations on a small building for use as a dispensary providing first aid to Jewish patients and as a centre for the sale of medicines. Macgowan even performed a few simple operations using equipment he had bought in Britain. ${ }^{19}$

In mid-1842 permission was received from London to set up a modest hospital, and Macgowan immediately began work. In September he managed to lease a building for a period of eleven years at $£ 25$ per annum. The building was close to the Society's dispensary on the eastern slopes of Mount Zion, facing the city and near the Jewish Quarter. The hospital was planned to hold a total of twelve beds

\footnotetext{
${ }^{17}$ Many of the mission societies in the nineteenth century - the "century of Great Missions"- used medical treatment as a tool for proselytizing, especially in China, India, and Africa.

${ }^{18}$ Archive of the London Jews' Society (LJS) in Jerusalem, held by the Israeli Trust of the
}

\author{
Anglican Church in Jerusalem (hereafter ITAC): \\ London Committee Resolutions, Nos. M1329, \\ M1330, M1337 (26.3.1841). \\ ${ }^{19}$ Archive of the LJS at the Bodleian Library, \\ Department of Western Manuscripts, Oxford, \\ Dep. Cmj, c.125: Lease agreements and the \\ purchase of parts of the pharmacy building.
}




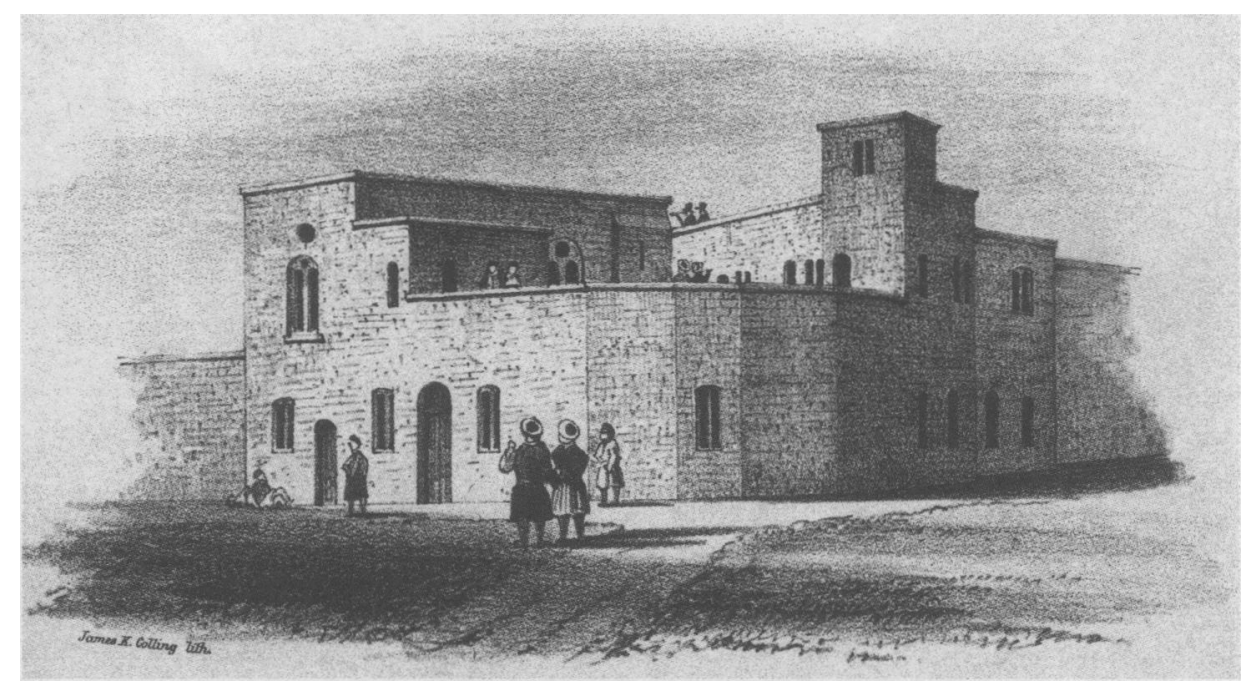

Figure 1: The Society's hospital in Jerusalem, 1844. (Keller House Archive (ILS-01), Haifa, Israel.)

on two separate floors, the lower one for men and the upper for women. Macgowan likewise proposed to set aside a separate wing for pilgrims and British tourists needing medical attention, and to charge them fees so as to cover expenses independently and even to generate income. ${ }^{20}$

On 12 December 1844 the English Mission Hospital in Jerusalem was opened and within days was filled to capacity. The new institution was a source of great pride for the missionaries, as expressed in their frequent reports to London. The Society's journal published many of Macgowan's letters, one of which described a typical day at the hospital:

It has frequently been my wish during the last month, that our friends in England could get a peep at the hospital on one of my days for the admission of patients. The scene that would meet their eyes would be one of uncommon gratification and interest. They would see the waiting room full of patients, besides a crowd of others thronging the doors of the hospital, who had been too late for admission, but who are patiently waiting, in the hope of being attended to when the first applicants shall be dismissed. Every three or four minutes the door of the consultation-room opens, and out comes a patient with his prescription in his hand, which he takes to the dispensary, which is situated on the other side of the street. This lasts for about two hours, during which the crowd of patients in the street are waiting-some standing, others seated, or lying on the ground or on the steps of the door. Some of them, naturally enough, lose patience, and, on the opening of the door, endeavour to force their way into the consulting-room, and are with difficulty prevented from doing so. Their turn, however, comes at last, when it becomes necessary to discriminate between those who really require advice, and those who are suffering from want. To the most necessitous of the latter

${ }^{20}$ Ibid., Listings of leases from Nov. 1843 until

Minutes Book, I, No. 57 (27.9.1842).

Sept. 1857; ITAC, Jerusalem Local Committee 


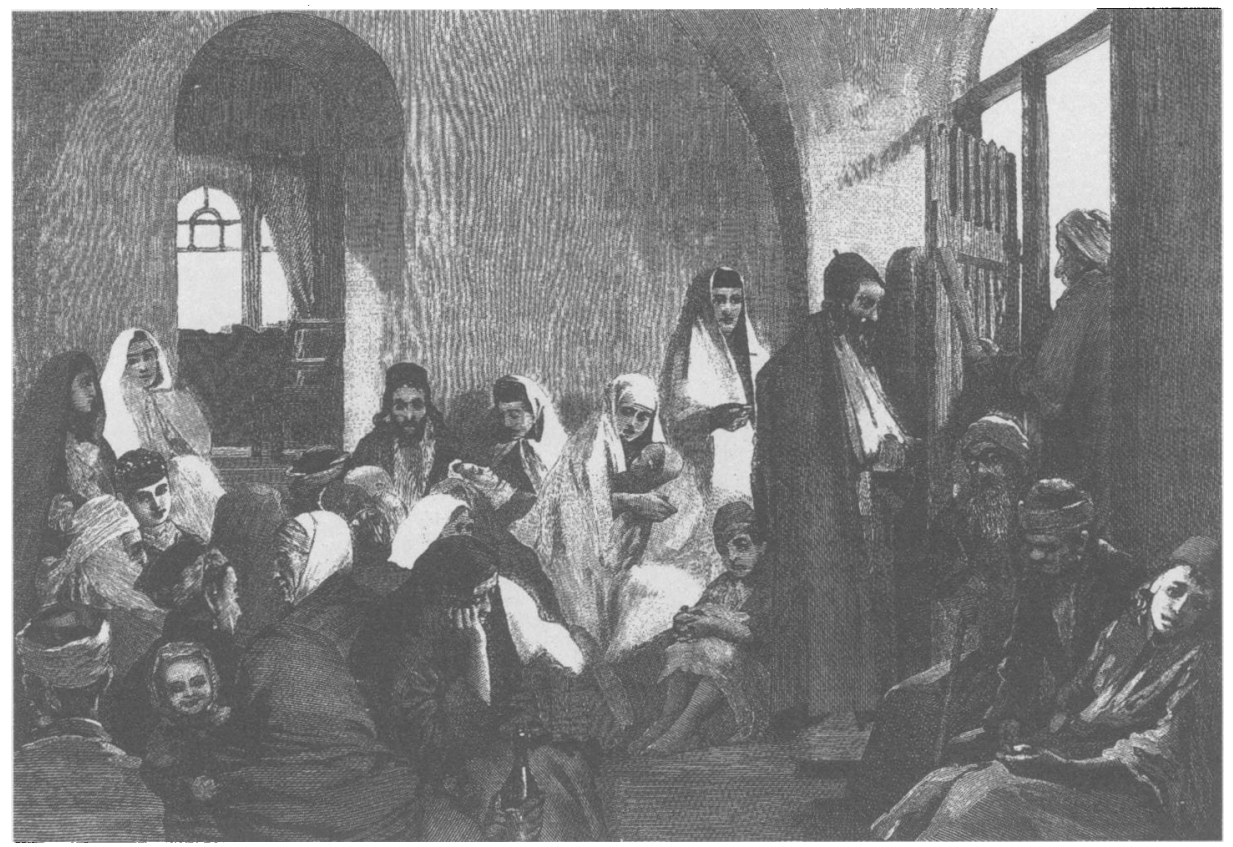

Figure 2: The hospital waiting room, $c$. 1870. Drawing by James Clark, from Fifty-two years medical work in Jerusalem, London, The London Society for Promoting Christianity amongst the Jews, 1892, pp. 28-9.

a ticket is given for the matron of the hospital, who is in attendance in an adjoining room, and who, on receiving the ticket, gives out of her stores which have been provided by the kind friends in England, some articles of clothing, flour, or relief in a little money, according to the wants of the applicant. ${ }^{21}$

Even before the dedication ceremony of the hospital, the missionaries in Jerusalem had anticipated opposition from the heads of the Jewish community to the hospitalization of Jewish patients in a Christian establishment. This was despite the experience they had gained while operating the dispensary for three years, during which time they had succeeded in serving a wide public. They tried to make things as easy as possible for the patients and those accompanying them, even setting up a kosher kitchen. But, in spite of the foreseen difficulties, the missionaries never expected the Jews to react as violently as they did.

The Jewish community in Palestine, because of its segregated character, used a variety of methods to draw back into its fold anyone who appeared to be on the verge of converting to Christianity. Heavy social pressure was brought to bear on the candidate for conversion, including the threat of divorce, the removal of children from parental care, and, finally, excommunication, which meant denial of the right to burial in a Jewish cemetery and no part in the world to come. But above all, the

\footnotetext{
${ }^{21}$ Jewish Intelligence, and Monthly Account of Promoting Christianity Amongst the Jews, Jan. the Proceedings of the London Society for 1847, p. 21: Macgowan from Jerusalem.
} 
community used the basics of economic survival-the charitable donations for distribution-to deprive the convert of his or her source of subsistence.

Six weeks after the opening of the medical establishment, a male patient died there. The two Chief Rabbis in Jerusalem made his burial according to Jewish rites conditional on all the Jews in the hospital, both patients and attendants, leaving it immediately, and on no Jew entering its gates in the future. Over the following week, several letters were exchanged between the rabbis and the hospital director, and between the latter and the British Consul in Jerusalem and the Foreign Minister in London. Since all these letters were fruitless, the missionaries were forced to bury the deceased patient in the British cemetery. ${ }^{22}$

The Jerusalem rabbis took this event so seriously that they proceeded to implement the gravest measure in their power. They issued the following ban:

All Israel shall hear and fear. As the horribleness in Israel upon Mount Zion, was clearly seen, from the affairs of the Freemasons' [sic] hospital, whose sole object[,] wish \& desire, by it, is to bring the souls of our brothers, of the house of Israel into their uncleanness ... By the power of our holy law ... we give notice that no man shall dare to enter the hospital above mentioned, whether a patient for his recovery, or a healthy person to serve there. Let both man \& woman take warning by this our edict. We also inform all our brethren of the house of Israel that whosoever shall enter the said hospital; their meat \& drink shall become, through a heavy excommunication[,] as unlawful food-their bread and wine shall become as the bread \& wine of idolaters, all their children will not be circumcized (amongst the holy assembly, neither will he be called up to the reading of the law) nor shall he have any part in the God of Israel, he will also not be purified, after his decease, by Jews, nor buried in their burial ground. We caution also the Shokhatim [ritual slaughterers] of all the congregations, not to kill a fowl for those, of the house of Israel, who shall enter the hospital. Likewise we charge our vendors of meat, by the same powers, not to sell meat to any man or woman, who shall enter the hospital; should they, however by any device, get meat from our vendors, then the dishes will be unlawful, the man or servant, through whom they got it, incurs the above mentioned curse. All the above mentioned curses shall be likewise upon every one, who will advise or induce any of the children of Israel, to enter the said hospital; but ye brethren, of the house of Israel, who cleave to the Lord, hear \& your soul shall live. Whosoever shall transgress this our edict, renders himself liable to all the penalties above mentioned; but good blessings \& prosperity will come upon those that hear our words. May the merits of our brethren of the house of Israel, \& of Jerusalem our holy \& glorious city defend us that none of us shall be led astray. Amen $\&$ so be the will of God! $!^{23}$

The implication of such a ban in those days meant the expulsion of the excommunicated person from the Jewish community or death by sheer deprivation. Its publication resulted in the complete desertion of the hospital by everyone within twenty-four hours.

\footnotetext{
${ }^{22}$ Archive of the British Foreign Office at the Public Record Office, London (FO), 78/625: W T Young in Jerusalem to Lord Aberdeen in London, 31 Jan.1845; ibid.: The Chief Rabbis to E Macgowan, 21 Jan. 1845; ibid.: E Macgowan to W T Young, 21 Jan. 1845; ibid.: E Macgowan to W T Young 22 Jan. 1845.
}

\footnotetext{
${ }^{23}$ Archive of the LJS in Jerusalem, ITAC, collection of unclassified documents: original letter of excommunication in Rashi script with a hand-written English translation alongside.
} 


\section{Yaron Perry and Efraim Lev}

Within a few weeks, the grim reality of the lack of medical services in Jerusalem made former patients appreciate the high medical standards of the Society's hospital and they retraced their steps to one of the few sources of medical care in the city. The hospital continued to function to the same standards for about fifty more years, during which time hundreds of Jews were hospitalized each year and tens of thousands of visits to the dispensary were recorded annually. ${ }^{24}$

\section{The New Hospital in Jerusalem}

In the mid-1870s rumours began to spread in Jerusalem and London concerning the need for a new hospital because of the dilapidated state of the old building and the increasing numbers of patients. However, it was only in September 1889 that the first decision was taken regarding the site for the proposed building. The London Society Committee in Jerusalem strongly recommended that the hospital be built outside the city walls on a stretch of land acquired in 1863 on which the Society's recreation site, called the "Sanatorium", was constructed in the same year. They envisaged the new institution as incorporating all the hospital's facilities, including the dispensary and staff quarters. The old hospital building inside the city walls would be retained for use as outpatient clinics and as a dispensary.

The plans for the new hospital were entrusted to Beresford A Pite, a British architect and a member of the London Society, who completed the assignment at the end of 1891. Pite's design consisted of separate buildings for each unit and department interconnected by covered walkways. This was to allow maximum ventilation in every part of the building and, by isolating patients, to prevent the spread of infectious diseases from one wing to another. Pite drew up these innovative plans after much thought and extensive viewing of similar institutions in Europe. At the dedication ceremony, he described the planning process: "Three years ago funds were sufficient for an inspection [sic] to come out and survey the spot. I visited about twenty different hospitals at that time. The principles of the erection of the present hospital are simple, the main object being to cure patients with as little medicine as possible, and give them as much light and sunshine as we can. We all notice how many windows and doors the building contains." 25

The new hospital for the Jews in Jerusalem, the flagship of the London Society in Palestine and the institution in which most of the funds and attention were invested, was dedicated on 13 April 1897. Taking part in the ceremony were some of its leaders from England, Thomas Chaplin, who was the hospital's director for twenty-five years, consuls of foreign countries, heads of churches in Jerusalem, representatives of the Turkish government, and all the London Society members in

\footnotetext{
${ }^{24}$ Ibid., Medical Reports 1842-1899, a handwritten journal of the Jerusalem hospital's directors.

${ }^{25}$ Jewish Missionary Intelligence, and Monthly Record of the London Society for Promoting
}

Christianity Amongst the Jews, July 1897, p. 105: detailed description of the building sections and their functions as an addendum to the panoramic photograph of the hospital. See ibid., Jan. 1898, pp. 8-9. 


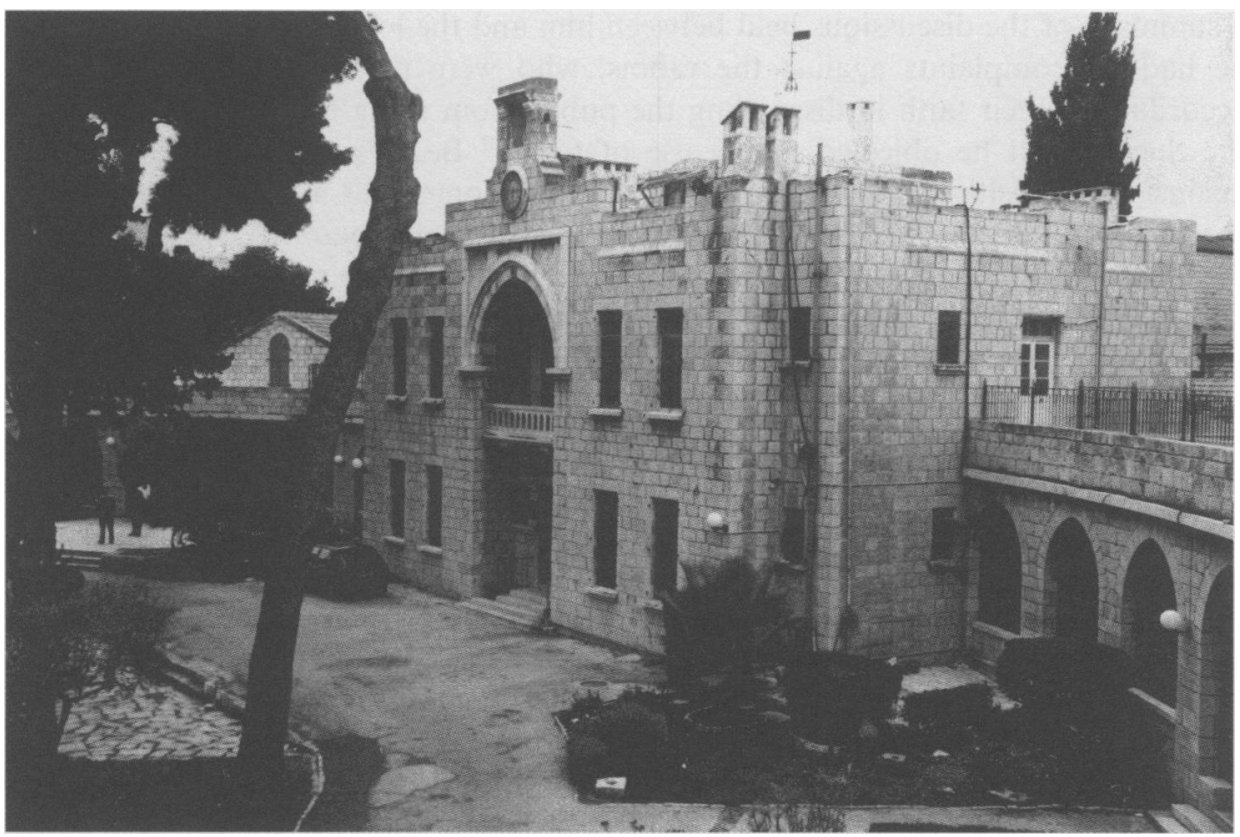

Figure 3: The former hospital in Jerusalem as it is today. It is now houses a school run by the Church Ministry among the Jewish People (originally the London Jews' Society). (Photo: Yaron Perry, 2001.)

Palestine; but not a single Jew was present. ${ }^{26}$ This absence was not fortuitous. The opening of this new hospital aroused fierce opposition, led mainly by an association called "Bnei-Israel" (Children of Israel), which had been founded in 1897 specifically to oppose this building. The association, which acted with the support of nearly all the Jewish communities, provided dispensaries and free medication to the Jews in Jerusalem. Its avowed objective was to "work for the unity of the congregations and for the improvement of the general situation". However, it mainly engaged in attempts to prevent by force the hospitalization of Jews in the London Society's new hospital.

Bnei-Israel lookouts were placed at the gates to prevent Jewish patients from entering, and it was not long before these men resorted to violence, at which point the people in the medical establishment and the guards of the British Consulate intervened. Riots ensured. A few days later, both the British ambassador in Constantinople and the Foreign Office in London took up the matter. Tempers were apparently cooled by an appeal made by Hastings Kelk, the head of the mission in Jerusalem, to the Jewish community in the Hebrew journal $\mathrm{Ha}$-Zevi, which published

${ }^{26}$ Archive of the LJS at the Bodleian, Dep. $\mathrm{Cmj}$, d.25: invitation to the inauguration events of the new hospital, signed by the head of the
Jerusalem Mission, Hastings Kelk and Percy d'Erf Wheeler, director of the hospital; ibid.: programme of the inauguration ceremony. 


\section{Yaron Perry and Efraim Lev}

a summary of the discussions held between him and the local rabbis. Kelk said that he had no complaints against the rabbis, who were merely fulfilling their duty according to their faith in dissuading the public from using the medical services of the Society, but he objected to the use of force. ${ }^{27}$ Besides the violence employed against those visiting the medical institution and sometimes against its employees, the members of the Bnei-Israel used other means to eliminate the "plague" called the Mission Hospital. The fact that it was built outside the walls of the Old City and that it was not possible to maintain close supervision over those entering its gates merely gave them an added incentive for their actions. For example, the BneiIsrael organization induced the highest religious court of the Jewish community to publish a sharp warning - one of many - that no Jew should use the services of the new hospital. The official declaration was as follows:

We heads and leaders of the holy congregation ... have unanimously decided to order a decree according to our rite, that it is unlawful for any "Shochet" [traditional slaughterer] to kill either beast or fowl for the use of the aforenamed Hospital, likewise it is unlawful for any Israelite to sell, provide, or permit to be sold any Kosher meat to the aforesaid Hospital. This prohibition applies to the sellers who sell directly or indirectly, and whoever transgresses these our commands, if he be a Shochet, whatever he killed will be considered "Nebela" (beast that dieth of itself), and if he be a butcher, he will not be trusted to sell Kosher meat, and supply them (the hospital), he will be dealt with according to our laws. ${ }^{28}$

Over the next four years, the London Society added other buildings to the hospital to complete the original plan. In the spring of 1898 it instructed the builders to continue with the construction of the Doctors' House at the site assigned for that purpose in the western wing of the hospital. On 11 July 1901 this was completed, together with another wing of the hospital dedicated to the memory of the philanthropist Richard Cadbury of Birmingham, who had died in Jerusalem. Thus the construction of the grand medical institution, which assumed a place of honour among the monumental nineteenth-century buildings in Jerusalem, was finally completed.

\section{The English Mission Hospital in Safed, Galilee}

Safed, being one of the four sacred cities of the Jewish people in Palestine and having a large Jewish population, held obvious allure for the London Society from the very first. Attempts to settle in the city had already been made during the exploratory expeditions of British missionaries in the 1820s, 1830s, and 1840s, but only at the height of the first wave of Jewish immigration to Palestine during the 1880 s did the Society begin its full-scale activities in this Galilean town. In the spring of 1884 a distinguished delegation set out from Jerusalem to ease the way for the

\footnotetext{
${ }^{27}$ On the stormy demonstrations and bans issued against the hospital see FO195/1984: a series of exchanges between John Dickson, British Consul in Jerusalem, and Philip Henry Wodehouse Currie, the Ambassador in Constantinople. On the guards stationed by the Jewish community leaders at the gates of the
}

\author{
hospital to prevent Jewish patients from entering \\ the institution, see ibid., 195/2028: P d'Erf \\ Wheeler to J Dickson. \\ ${ }^{28}$ Jewish Missionary Intelligence, Aug. 1897, \\ p. 115: the decree was translated into English and \\ signed by the Chief Rabbi.
}




\section{The Medical Activities of the London Jews' Society}

opening of the Safed mission station and to post an emissary and a physician in town. In June 1893, Dr Ernest Masterman, who had served at the Jerusalem hospital and then moved to Safed, sent the London Society leaders his impressions regarding the urgent need for a real hospital:

There is not one single Hospital in the whole town. Such a state of things does not exist elsewhere in Palestine. Practically, all the large towns in the country have well-appointed Medical Missions; but these are no good to those really ill in Safed, as a journey even to so near a place as the Scotch Mission [Hospital] in Tiberias, can only be made by difficult mountain roads. In Tiberias $(4,000$ inhabitants), the Scotch now have a Hospital, and are building a new and substantial one on the shores of the lake. In Nazareth (7,500 inhabitants), the Edinburgh Missionary Society has a long-established Medical Mission, with a small Hospital. At Nablous (20,000 inhabitants) [should be 13,000] the C.M.S. [Church Missionary Society] has a flourishing Medical Mission, only recently started, but with a Hospital and a salaried nurse. At Haifa (8,000 inhabitants), I understand our Bishop has a small Hospital attached to his Medical Mission. At Jaffa (23,000 inhabitants) there is, as you know, a longestablished Medical Mission Hospital, with a large staff of nurses. The Roman Catholics also have a fine Hospital. At Hebron (10,000 inhabitants) Mrs. Meredith has also Hospital premises, and a Scotch doctor ... is now at Constantinople taking his diploma preparatory to taking charge. The Jews are also building a small Hospital there. I quote the above to show that these towns (though all smaller than Safed) have well-appointed Medical Missions, with Hospitals; while we in Safed, though having so long established a work there have no Hospital, in spite of the fact of the needs being much greater. ${ }^{29}$

This strongly worded report attracted a great deal of attention in London. As a result of its publication, explicit instructions were sent out to obtain permission for building "a small hospital" on land belonging to the London Society in Safed. However, the success of the medical enterprise in the city led to a change of plan, and attempts were made to locate an additional plot of land to build a more spacious hospital. To carry out this project, Dr Walter Henry Anderson, a native of Burtonon-Trent, and a Licenciate of Edinburgh's Royal College of Physicians and of its Royal College of Surgeons, was appointed to head the medical department so that Masterman would be free to return to his duties in Jerusalem. As soon as he arrived in April 1894, Anderson threw himself into his work, declaring that he saw his position in Safed as his vocation in life. His first recommendation was to open a small hospital of six beds immediately, and at the same time to continue efforts to set up the projected large hospital. The London Society approved of his proposal and, at the end of 1895 , he rented a building to be used as a hospital for a period of three years, which was opened in February 1896.

In 1898, Anderson managed to obtain a permit from the local authorities to build a residence for his family in the compound (purchased in 1895) intended for a

${ }^{29}$ Jewish Missionary Intelligence, Oct. 1893, p. 146. The population figures given in square brackets are taken from Y Ben-Arieh, 'Ha-nof ha-yshuvi shel Eretz Yisrael erav ha-hityashvut ha-zionit' ('The landscape of Palestine on the eve of the Zionist colonisation', in I Kolatt (ed.),

Toldot ha-yshuv ha-Yehudi be-Eretz Yisrael me-az
ha-Alyia ha-Rishona. Ha-tkufa ha-otmanit (The history of the Jewish community in Eretz-Israel since 1882: the Ottoman period), part 1, Jerusalem, The Israel Academy for Sciences and Humanities and The Bialik Institute, 1989, pp. 75-141. 
hospital with the hope of receiving, in time, authorization to build the hospital itself. $\mathrm{He}$ also reported to the London Society that at the end of June he had signed an agreement with the German building consultant in Haifa, Gottlieb Schumacher, for constructing the house. Schumacher was asked to start designing the hospital as well, and towards the end of 1899 he completed the first draft of his plans and sent them to the Society's leaders. At the end of May construction began.

At first progress was very slow. Anderson sent a letter from Safed complaining of the distress suffered at the temporary hospital and emphasizing the urgent need to accelerate the building of the permanent medical institution:

I only wish I had the power vividly to bring before the Committee the misery of continuing to carry on the work in the present most wretched premises... At the present time I am obliged to perform surgical operations in the wards with a screen round the operation table! The so-called operation room defies description; the walls are reeking with damp, and the plaster falling off in all directions ... If the new Hospital is not ready for occupation by the time winter has well commenced, I shall have to definitely advise the Committee to close that branch of the Medical work temporarily. ${ }^{30}$

A few months later, Anderson once more complained about the state of the temporary hospital and noted that the lease would expire in September. He claimed that, because of its dilapidated condition, the building could no longer serve its purpose even if the lease were extended for another year. He therefore recommended renting another building until the expected opening of the new hospital in the summer of 1904 , or alternatively, closing down the medical ward completely. It appears that in the autumn of 1903 Anderson's April foreboding was realized. The doctor preferred not to continue using the damp and decrepit building any longer, since in winter it was better to place the patients outside the institution, under the open sky. ${ }^{31}$ Medical activity ceased and efforts were made to find another house to rent while the permanent hospital was being completed.

On 31 May 1904, the new hospital was inaugurated in Safed. The four-storey building was equipped with the best medical refinements available and contained, besides hospital wards for forty patients, a modern operating theatre and a kosher kitchen. This up-to-date institution fired the imagination of the editor of the Jewish Missionary Intelligence in London. He published an article written by Anderson, who described in great detail every aspect of the institution, taking the readers on a complete tour of the interior:

Upon entering we are at once struck by its brightness and English-like appearance. The floors are composed of white cement tiles, with a border of black. The walls are tinted a soft, pink colour. The modern English fireplace, with turquoise blue tiles and white enameled mantelpiece, at once arrests the attention of the English traveller, who has probably not seen the like since leaving the homeland. ${ }^{32}$ p. 71.

${ }^{30}$ Jewish Missionary Intelligence, May 1903,

${ }^{31}$ Archive of the LJS at the Bodleian, Dep. Cmj, d.64: W H Anderson to the Secretary of the
London Society, 2 July 1903; Jewish Missionary

Intelligence, Oct. 1903, pp. 151-4.

${ }^{32}$ Jewish Missionary Intelligence, June 1905, p. 84 . 


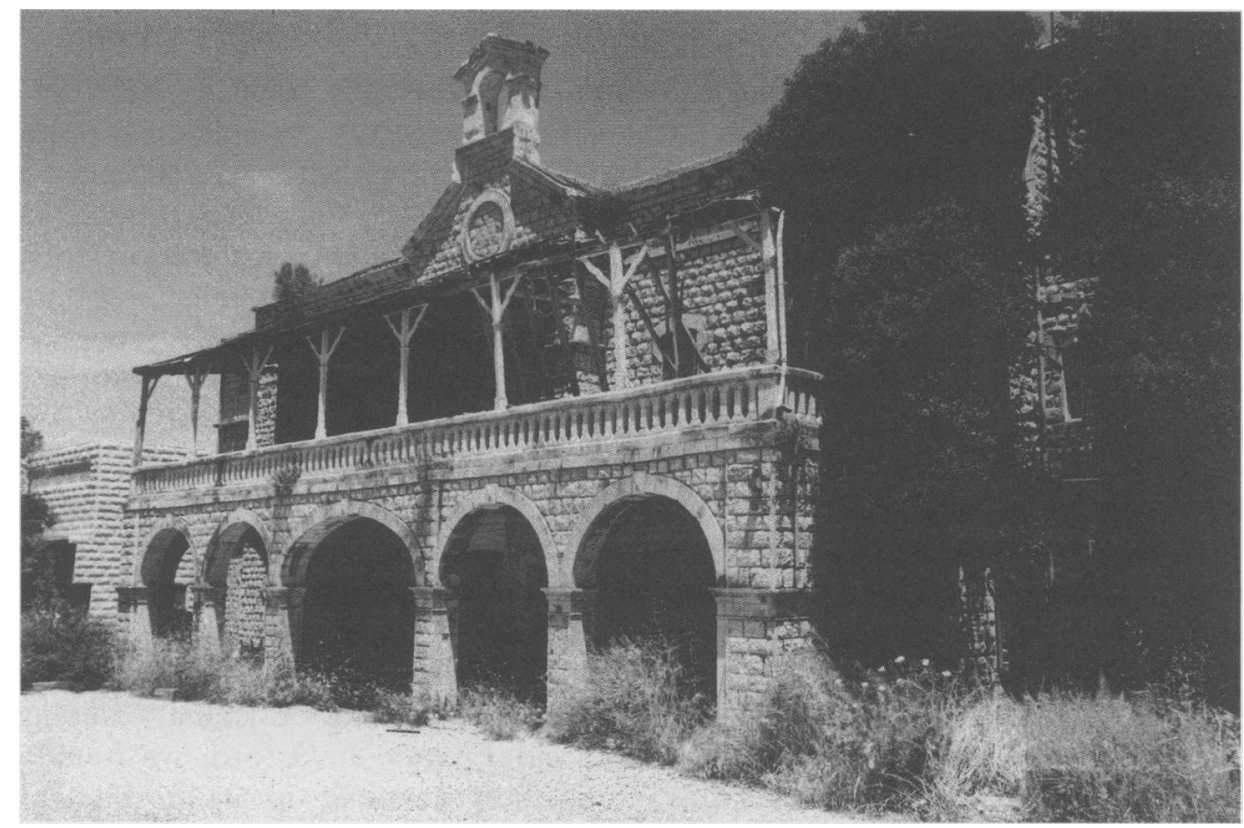

Figure 4: The hospital in Safed, Galilee, as it is today. (Photo: Yaron Perry, 2001.)

Since the hospital was the only medical institution in the city to serve the Jews in the Galilee settlements as well, for the very first time at an event of this kind many of the Jews of Safed participated in the dedication ceremony. A few years later, in a speech in London on the situation at his medical institute, Anderson presented a lucid analysis of the Jewish community's attitude to the hospital, and epitomized it in one sentence: "A few years ago the difficulty with us was how to get at these fanatical people in Safed; now the difficulty is not how to get at them, but how to get away from them." ${ }^{33}$ He exaggerated, but the spirit of good will among the Jews, which enabled them to continue using the hospital, persisted in Safed. The extent of the hospital's success can be learned from the text of a Jewish ban publicly displayed in the city:

In our city the work of the mission is more than in any of the holy cities; the enticers labour day and night, and use every means to draw our brethren to them, especially the young. Their doctors heal all Jewish patients gratis, as if the Christian religion enjoins to pity only [emphasis in original] the Jewish poor, and by this means about fifty Jews (even of the most pious) listen daily to the addresses from the preachers, causing them to go astray ... ${ }^{34}$

${ }^{33}$ Jewish Missionary Intelligence, June 1907, p. 93: Anderson's speech before the London Committee, 3 May 1907. p. 68 .

${ }^{34}$ Jewish Missionary Intelligence, May 1907, 
Pharmacological and Medical Aspects of the Society's Jerusalem Hospitals

Clinics and hospitals in distant lands and underdeveloped countries were not a unique or exceptional phenomenon in the nineteenth century. As a colonial power, Britain provided advanced medical services for its citizens who were stationed as government officials, military personnel, or merchant traders in every corner of the globe. As proof of this, the medical press in England ran regular features on British medical activities around the world, printed "Wanted" columns for enlisting doctors and pharmacists for medical work in the colonies, and even published reports on military medicine abroad. Detailed and accurate reports were part of the culture of governing, and made the existence of a colonial empire possible. This had been an ingrained feature of British colonial practice for centuries, and the medical staff serving in the Society's Jerusalem hospitals acted in the same spirit. Although the hospitals functioned as private institutions belonging to a philanthropic organization, strict regulations regarding the keeping of records and drawing up of reports were observed.

In our study of the medical activities of the mission in Jerusalem recorded in the archival documents of the London Society for Promoting Christianity amongst the Jews, which are deposited in the Bodleian Library at Oxford, we found a large number of documents relating to medical activities in its hospitals in Palestine. They include medical reports, plans for the construction of medical institutions, and personnel matters, as well as publications about these institutions and extensive correspondence. From that rich archival collection we present here one document that sheds light upon the medical methods practised in the early period of the hospital. This inventory of medications in the store of the dispensary at the Jerusalem hospital lists 268 items on nine pages in partially legible handwriting and is entitled 'List of Medicinal Preparations Found in Store and Dispensary on July $21,18577^{35}$

Table 1

\begin{tabular}{lcc}
\hline Origin/Source & Number of substances & Percentage \\
\hline Plants & 147 & $54.8 \%$ \\
Chemicals and Minerals & 117 & $43.7 \%$ \\
Animals & 4 & $1.5 \%$ \\
Total & 268 & $100 \%$ \\
\hline
\end{tabular}

Table 1 shows the quantities of medicinal substances held in the English Mission

\footnotetext{
${ }^{35}$ The handwriting was deciphered with the assistance of the following nineteenth-century medical and pharmacological studies: W Woodville, Medical botany, 4 vols, London, W Phillips, 1819, vols. 1-2; W Lewis, $A$ complete dictionary of the whole materia medica, 2 vols, London, Johnson, 1810; British pharmacopoeia,
}

1858, 4th ed., London, Spottiswoode, 1880; A Duncan, The Edinburgh new dispensatory, Edinburgh, 1804. The writers wish to thank Dr Tilli Tansey of the Wellcome Trust Centre for the History of Medicine at University College London for her kind assistance. 


\section{The Medical Activities of the London Jews' Society}

Hospital for the Jews in Jerusalem in 1857. A comparative examination shows that the list includes a quarter of the materia medica then known and applied in Britain ${ }^{36}$ and altogether about a third of the British pharmacopoeia of 1858 , which comprised 734 medicines. ${ }^{37}$ Similarly, a comparison made between the list and the standard contents of clinics shows that the stores of the hospital and clinic in Jerusalem contained about 80 per cent of the products used at that time. ${ }^{38}$ Most of the raw materials for preparing the medicines were imported from Britain, including many found in abundance in Palestine, in the open fields and in the markets. Among those derived from plants are several originating in Asia, India (ipecacuanha, cajuput), Africa (kino), and America (sassafras, cinchona). The use of substances from the New World was characteristic of modern medicine, but previously in the Levant only quinine had been used by the Franciscan monks in Jerusalem in the eighteenth century. ${ }^{39}$

The only animal substances in the list are ambergris (the intestinal secretion of the sperm-whale), Spanish fly (a medically active ingredient generally associated with reinforcing the sex drive), lard, and animal charcoal. These were widely used in the past as medications and are prevalent today in traditional medicine practised throughout the Middle East. By comparison, in the region of Greater Syria during the Middle Ages and the Ottoman period, records exist indicating the use in scholarly medicine of substances from thirty different kinds of animals. ${ }^{40}$

Many of the substances found in the list could have been obtained in the Jerusalem marketplace: aloe vera, camphor, cardamon, cinnamon, galanga, galbanum, gallnut, gum-arabic, iron, lead, myrrh, nutmeg, pepper, pine resin, rhubarb, soap, sulphur, and zinc. Also listed were products plentiful both in the wild and in cultivation, such as almond, bindweed, bitter apple, castor oil, laburnum, liquorice, pistachio, squill, and water-melon.

Additional plants appearing in the list could easily have been grown in the garden of the British clinic in Jerusalem: rosemary, lavender, basil, anise, and saffron. As noted above, Macgowan, the founder of the hospital, urged the leaders of his Society in February 1842 to allow him to lease a plot of land adjoining the institution and employ a local worker to cultivate a garden so that "it would be possible for the Medical Department to save expenses by growing medicinal plants". ${ }^{41}$ However, even if the hospital staff had grown these plants in their garden, or collected them from the open fields, it would still have been necessary to extract the oils from them, produce the powders, collect the resinous juices, and so on. Such processes would have needed professional skills, expensive training, and reliable workers over a prolonged period of time. The medical staff undoubtedly preferred to purchase the oils, essences, and powders from Britain where they were produced in mass quantities

\footnotetext{
${ }^{36}$ See Lewis, op. cit., note 35 above.

${ }^{37}$ See British pharmacopoeia, 1858, op. cit., note 35 above.

${ }^{38}$ See Duncan, op. cit., note 35 above.

${ }^{39}$ Horn, op. cit., note 7 above, p. 181 .

${ }^{40} \mathrm{E}$ Lev, 'Ha-shimush ha-refu'i be-va'aleh hayim ve-tozrotehem be-Eretz Yisrael u'be-
}

svivotehah bi-yemeh ha-benayim' ('The medicinal uses of animals and their products in the Medieval Levant'), Harefua, 2000, 139: 483-7.

${ }^{41}$ Archive of the LJS in Jerusalem, ITAC, medical diaries of the clinic, Aug. 1845, p. 112. 


\section{Yaron Perry and Efraim Lev}

by industrial processes and were of high quality, although they may have suffered from the long journey.

A consignment took several weeks to arrive by ship from Britain, and was then transported from Jaffa to Jerusalem by mule-caravans. This would explain Macgowan's desire for a garden. Another possible explanation could have been the Society's financial situation, which allowed it to purchase only the main, basic substances. The traditional substances in the medical stores of the British hospital in Jerusalem constituted more than half the listed items, and their medical importance was therefore relatively high. These substances seem gradually to have disappeared, and they are barely mentioned in the pharmacological framework of conventional medicine. However, they did not disappear entirely, and some of them were to perform a major function in the stores of alternative medicine, which is very popular today among the sick and ailing.

A comparison between the 1857 list and the historical evidence of medicinal substances used in the Levant from the Muslim conquest in the seventh century to Napoleon's campaign at the end of the eighteenth century shows a decline in the number of plants used as a basis for medications from 234 to 169 (plants were often used as ingredients in chemical compounds). The number of animal-based products fell from 30 to 4 . In the 1857 list, 117 chemicals and minerals are named-a new and significant factor in medicine; in fact, they replaced the minerals used in medicines before the sixteenth century, which usually constituted 5 to 10 per cent of medicinal agents (see Table 2). ${ }^{42}$

A study of the list of popular medicinal substances described by the Swiss physician, Titus Tobler, after his visit to Jerusalem in 1845, also proves that the products in the Jerusalem markets and in the Franciscan, Greek, and Jewish dispensaries could have assisted the English Mission Hospital in time of need. During an earlier visit to the Franciscan dispensary in 1835, Tobler wrote in his notebook: "If only half of what is indicated on the boxes and jars is correct-there is a rich treasure of medications here ... but the storehouse of medicines was exceptionally good ... there were some excellent pieces of medicinal bindweed ${ }^{43} \ldots$ the Jerusalem balsam ${ }^{44}$ is still available from the monks." ${ }^{45}$ On his visit to the marketplace, he described the contents of a stall selling traditional medicinal substances, some of which are listed in the English hospital inventory. He was especially impressed by the cleanliness of the Greek dispensary: "Of all the dispensaries in Jerusalem, the Greek one is exceptional for its cleanliness, brightness and well-ordered arrangements. The inscriptions were in splendid Greek lettering." His visit to the Jewish dispensary was summed up as follows: "The Jews have medicine merchants in their quarter so that their dispensaries are better stocked. Two of them are especially worthy of mention ... the inscriptions are in Hebrew lettering. Cleanliness is non-existent ... What $I$ tried unsuccessfully to find among the Moslems, I found among the Jews: kalomel,

\footnotetext{
${ }^{42}$ E Lev, 'Reconstructed materia medica of the medieval and Ottoman al-Sham', J. Ethnopharmacol., 2002, 80: 167-79.

${ }^{43}$ About bindweed, see Amar and Lev, op. cit., note 1 above, pp. 182-3.
}

\footnotetext{
${ }^{44}$ About balsam, see Bagatti op. cit., note 10 above, pp. 250-361; Cirelli op. cit., note 10 above, p. 219.

${ }^{45}$ Tobler, op. cit., note 14 above, pp. 14-15.
} 
Table 2

The fifth table out of thirteen found in the list of medicinal substances at the British Hospital for the Jews in Jerusalem in 1857

Metallic Salts

\begin{tabular}{|c|c|}
\hline Original text (handwritten) & Scientific/English name \\
\hline Ferri Sulphatis & Sulphate of Iron \\
\hline Ferri Cyanide & Cynaic of Iron \\
\hline Ferri Carbonat Sacchar. & Carbonate of Iron (Sug) \\
\hline Ferri Tartarizata & Tartrate of Iron \\
\hline Ferri Carbonatis & Carbonate of Iron \\
\hline Ferri Sesquioxi & Hydrated Peroxidum of Iron \\
\hline Ferri Tartratis & Tartrate of Iron \\
\hline Ferri Iodusetic & Iodine of Iron \\
\hline Ferri Ammoniaca chlor. & Ammon. Chlo. of Iron \\
\hline Ferri Ammonia tartrat & Ammo. Trat. of Iron \\
\hline Ferri Ammonia Citrat & Ammo. Citr. of Iron \\
\hline Ferri Citrat e Quinie & Citrate of I. E Quinine \\
\hline Ferri Percitrate & Ctr. Peroxide of Iron \\
\hline Ferri Pot. Tartratis & Tartrated Iron \\
\hline Plumbi Acetatis & Acetate of Lead \\
\hline Plumbi Oxide & Oxide of Lead \\
\hline Plumbi Carbonat & Carbonate of Lead \\
\hline Hydrogyri chloride & Carbonate of Mercury \\
\hline Hydrogyri bichloride & Perchloride of Mercury \\
\hline Hydrogyri Binioxide & Oxide of Mercury \\
\hline Hydrogyri nitro-Oxide & Red Oxide of Mercury \\
\hline Hydrog. Nit.-Ox. Living & Red Oxide of Mercury \\
\hline Hydrogyri Peroxidi & Peroxide of Mercury \\
\hline Hydrogyri Jodide & Iodine of Mercury \\
\hline Hydrogyri Bisulph. & Bisulphate of Mercury \\
\hline Hydrongyrum metallic & Metallic Mercury \\
\hline Hydrog. e crita & Mercury with Chalk \\
\hline Zinci Oxide & Oxide of Zinc \\
\hline Zinci Chloride & Chloride of Zinc \\
\hline Zinci Jodidi & Iodine of Zinc \\
\hline Zinci Sulphate & Sulphate of Zinc \\
\hline Zinci Acetat & Acetate of Zinc \\
\hline Zinci Valerianatic & Valerianate of Zinc \\
\hline Arsenici Jodidi & Iodine of Arsenate \\
\hline Arsenious Acid & Acid of Arsenate \\
\hline Antimon Pot. Tart. & Trat. Pot. of Antimon \\
\hline Antimonalis Pulv. & Antimon Powder \\
\hline Iodininum & Iodine \\
\hline Sulphuris Jodidum & Sulphate Iodine \\
\hline Strontia Carb. & Carbonate of Stronia \\
\hline Barri Sulphanti & Sulphate of Barium \\
\hline Manganese Oxidi & Oxide of Magnesium \\
\hline Bismuthum Oxide & Oxide of Bismuth \\
\hline Bismuthum Trisnitr & Nitrate of Bismuth \\
\hline Cupri Acetatis & Acetate of Copper \\
\hline Cupri Sulphatis & Sulphate of Copper \\
\hline Argenti Nitrate & Nitrate of Silver \\
\hline Potassa pura. & Pure Potash \\
\hline Potassa e Calc. & Potash and Calcium \\
\hline
\end{tabular}




\section{Yaron Perry and Efraim Lev}

opium essence, and treacle (theriack)." In the following sentence, Tobler indirectly sums up the connection between traditional medicine with its medicinal substances and modern medicine in its infancy: "Had there not been dispensaries among the Franciscans, the physicians could have obtained the most essential things here on condition they were able to read the writing ... and Jews have been selling medicines for a very long time." ${ }^{46}$

The 1857 list is, therefore, historical proof of a turning point in the medical history of Palestine. It is one of the first written testimonies to modern medical and pharmacological activity in the Levant in general and in Palestine in particular. For millennia, the lists of medicinal agents used contained a fixed proportion of substances according to their origins (plant, mineral, and animal). The composition of this list testifies above all to the increasing use of various chemicals as medicines, or as components of medications, together with plants, minerals, and animal substances. The growing use of chemicals and minerals occurred at the expense of products derived from animals, and of substances of indefinite origin.

\section{Conclusion}

The standard of medical care in a country can be evaluated in a number of ways, through the public health system, medical training, and medicinal substances. When the medical services of the London Jews' Society in nineteenth-century Palestine are compared with those available decades earlier under the Ottoman medical system, and even with the Franciscan medical institution, the only foreign establishment operating in Palestine at that time, the British are seen to have instituted a new era, the era of modern medicine.

A detailed examination of the Society's activities show that it brought about significant changes. First, the London Jews' Society was the first to supply the Jews of Palestine with well-equipped hospitals in the European style and a modern dispensary, in which new medical techniques and treatment such as anaesthesia with chloroform were used. Second, the British physicians were graduates of fine British and European medical schools and had acquired their training in prominent hospitals in Britain. ${ }^{47}$ During their service in Palestine they often conducted scientific research, mainly in medicine, archaeology, and theology, the results of which were published in several important international journals. ${ }^{48}$ Third, a wide variety of modern medical tools as well as medicinal materials were brought from Britain and used by the Society's British physicians in accordance with the latest medical and pharmacy manuals. One of the best pieces of historical evidence for this turning point in the medical history of Palestine is the list of medicinal substances discussed above.

\footnotetext{
${ }^{46}$ Ibid., pp. 15-17.

${ }^{47}$ See, for example, Dr Chaplin's registration, The Medical Register, London, 1885, p. 219; 1863,

${ }^{48}$ For example, Chaplin, op. cit., note 14 p. 69 .
} 


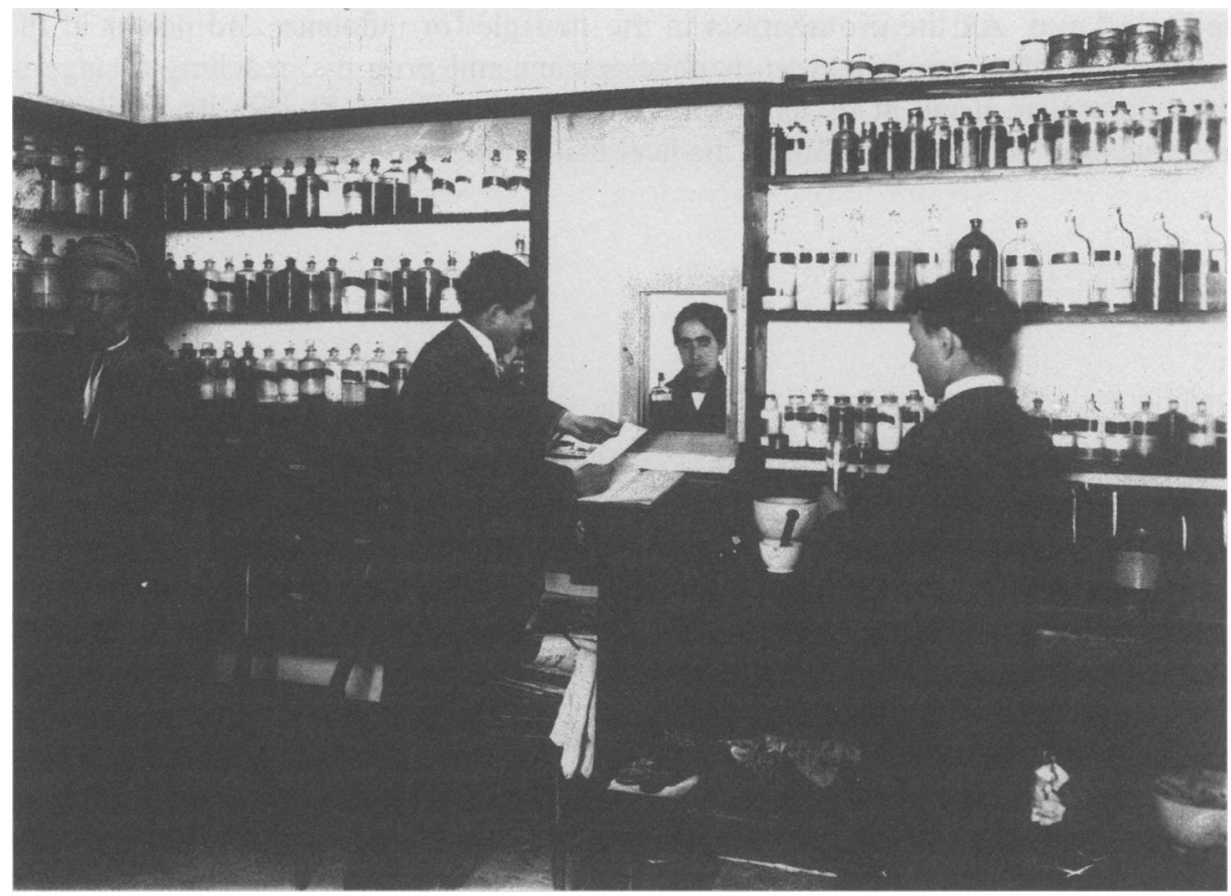

Figure 5: The dispensary in Jerusalem, c. 1900. (Archive of the London Jews' Society, St Albans.)

Good as they seemed, the endeavours of the London Society fell prey to sharp criticism from all directions. Many of the condemnations came from Greek Orthodox and Catholic representatives in Palestine, who regarded the Society's Protestant operations as an invasion of their territory and an impediment to their advancement. Naturally, censure also came from the leaders of the Jewish community, who regarded even the very small number of converts as a catastrophe and fiercely denounced the missionaries. An abyss opened wide between the missionaries and the Jewish community on that account. The only ray of light in the relationship of the London Society's emissaries and the Jews in Palestine flickered in the corridors of the English Mission Hospitals, where Jewish patients were cared for, and where the barriers of prejudice began to give way to a certain extent.

The fact that the Society was the first among various missionary societies in Palestine to establish health, education, charity, and welfare institutions, forced its opponents to stay alert and initiate similar projects if they wished to retain the loyalty of their flock. The heads of the Jewish community in Palestine and the Diaspora were obliged to establish hospitals, schools, and many other organizations as quickly as possible in order to match those of the London Society. Even the great powers were quick to follow suit, by posting high-ranking officials of their own in Palestine and establishing many modern institutions there. A race got under way in 
the Holy Land. All the protagonists in the struggle for influence and power in the region eventually contributed to its development and progress, reaching a stage in which Jerusalem itself, at the end of nineteenth century, could offer its inhabitants the services of more than a dozen medical institutions. 